\title{
Conservation of gene arrangement and an unusual organization of rRNA genes in the linear chromosomes of the Lyme disease spirochaetes Borrelia burgdorferi, B. garinii and $B$. afzelii
}

\author{
Caroline Ojaimi, ${ }^{1}$ Barrie E. Davidson, ${ }^{1}$ Isabelle Saint Girons ${ }^{2}$ and \\ lain G. Old ${ }^{2}$
}

\author{
Author for correspondence: Barrie E. Davidson. Tel: +613344 5912. Fax: +613347 7730. e-mail \\ davidson@ biochemistry.unimelb.edu.au
}

1 Russell Grimwade School of Biochemistry, University of Melbourne, Parkville, Victoria 3052, Australia

2 Unité de Bactériologie Moléculaire et Médicale, Institut Pasteur, 75724 Paris Cedex 15, France

\begin{abstract}
Physical maps of the chromosomes of the Lyme disease spirochaetes Borrelia garinii and Borrelia afzelii have been elucidated for the enzymes Cspl, SgrAl, I-Ceul, Smal, Eagl, BssHII, Mlul and Apal by two-dimensional pulsed-field gel electrophoresis techniques. The maps contain 42 sites for B. garinii and 32 for $B$. afzelii. The mapping studies showed that the two chromosomes are linear DNA molecules of 953 and $948 \mathrm{kbp}$, respectively. A comparison of the physical maps of B. garinii and B. afzelii and the published map of the other Lyme disease spirochaete, Borrelia burgdorferi [Davidson, B. E., MacDougall, J. \& Saint Girons, I. (1992) J Bacteriol 174, 3766-3774] revealed that the three chromosomes have few endonuclease sites in common, apart from a cluster in rrl (encoding 235 rRNA) and rrs (encoding 165 rRNA). Cloned borrelial genes were used as specific hybridization probes to construct genetic maps, using the physical maps as a basis. The resulting maps contain 41 genetic loci for $B$. burgdorferi, 39 for B. garinii, and 33 for B. afzelii. In contrast to the physical maps, the three genetic maps are closely related, with no detectable differences in gene order along the entire length of the chromosome. It is concluded that the chromosomes of these three borrelial species have undergone no major rearrangements, deletions or insertions during their evolution from a common ancestor. Detailed mapping of the region of the $B$. garinii and B. afzelii chromosomes that encodes rRNA revealed that each chromosome contains one copy of rrs separated by $5 \mathrm{kbp}$ from two copies each of $r r l$ and $r r f$ (encoding $5 S$ rRNA). The gene order is rrs rrlA rrfA rrlB rrfB. B. burgdorferi is the only other member of the eubacteria for which this particular rRNA gene arrangement has been observed. A DNA length polymorphism in the region of the borrelial rRNA genes was shown to be due to the presence of $\mathbf{2 \cdot 2} \mathrm{kbp}$ more DNA between rrs and rrIA in B. garinii and B. afzelii than in B. burgdorferi.
\end{abstract}

Keywords: Borrelia, linear bacterial chromosome, genetic map, rRNA operon, DNA length polymorphism
Abbreviations: $r r s, 165$ rRNA gene; $r$ l, 235 rRNA gene; $r$ rf, 55 rRNA gene; PFGE, pulsed-field gel electrophoresis.

The GenBank accession numbers for sequences reported in this paper are L32145 (gb_ba:BORHTPG) for htpG; L32146 (gb ba:BORMETG) for metG; L32595 ( $\mathrm{gb}$ ba:BORPGKTPI) for pgk and tpi; L32596 (gb ba:BORLYME) for the PCR target; L32861 (gb ba:BORPLSCTOP) for plsC and parE; L35050 (gb ba: BORBMPA) for tmpC.

\section{INTRODUCTION}

The spirochaete Borrelia burgdorferi, first reported and described in 1984, is a causative agent of Lyme disease (Burgdorfer et al., 1982; Johnson et al., 1984). DNA-DNA hybridization of Borrelia isolates from 
around the world has revealed a more complex taxonomy of the Lyme disease spirochaetes than was originally thought. At least two additional new species (Borrelia garinii and Borrelia afzelii) capable of causing the disease are now recognized (Baranton et al., 1992; Canica et al., 1993). All three species have been isolated in Europe whereas only B. burgdorferi sensu stricto is found in the USA. An understanding of the taxonomy of these spirochaetes is important since certain clinical aspects of Lyme disease are dependent on the identity of the infecting organism. Thus, arthritis is associated more commonly with $B$. burgdorferi sensu stricto infections, meningoradiculitis with $B$. garinii infections, and cutaneous manifestations with $B$. afzelii infections (Assous et al., 1993). Genetic analyses of these different species therefore has the potential to provide important insights into the molecular basis of Lyme disease and its wide spectrum of symptoms.

Interest in the molecular genetics of B. burgdorferi sensu lato (for a review see Saint Girons et al., 1994) was heightened by the discovery that its chromosome is linear and not circular like those of other characterized bacteria (Baril et al., 1989; Ferdows \& Barbour, 1989). The chromosome was also found to be small, around $1 \mathrm{Mbp}$ (Baril et al., 1989; Ferdows \& Barbour, 1989). Physical mapping studies yielded results that were consistent with linearity and provided chromosome sizes of 946 and $952 \mathrm{kbp}$ for $B$. burgdorferi strains 212 and Sh-2-82, respectively (Davidson et al., 1992; Casjens \& Huang, 1993). A comparison of the chromosomal maps of the two strains revealed that 33 out of the 41 cleavage sites of the six endonucleases used in both mapping studies were conserved (Casjens \& Huang, 1993). Details of the molecular structure of the extremities of the chromosome have not been reported, although the telomeres of a $16 \mathrm{kbp}$ linear plasmid also present in $B$. burgdorferi are covalently closed and their nucleotide sequences have been determined (Hinnebusch et al., 1990; Hinnesbusch \& Barbour, 1991).

The rRNA gene organization in B. burgdorferi is also unusual. The chromosome carries a single gene encoding $16 \mathrm{~S}$ rRNA ( rrs) separated by $2.7 \mathrm{kbp}$ from a tandemly repeated pair of $23 \mathrm{~S}(\mathrm{rrl} A$ and $\operatorname{rrl} B)$ and $5 \mathrm{~S} \operatorname{rRNA}(\operatorname{rrf} A$ and $r r f B$ ) genes (Davidson et al., 1992; Schwartz et al., 1992; Fukunaga \& Sohnaka, 1992; Gazumyan et al., 1994). This gene organization contrasts with the situation in most bacteria, which have one or more rRNA operons each containing one copy of $r r s, r r l$ and $r r f$.

The small size of the chromosome of Lyme disease spirochaetes makes them useful organisms for interspecies comparative studies aimed at providing insights into chromosome evolution. We have therefore commenced an investigation of the genetic relationship between $B$. burgdorferi, B. garinii and B. afzelii. In this paper we present data on the elucidation of physical and genetic maps of the B. garinii and B. afzelii chromosomes. The new maps have been compared with previously published physical and genetic maps of the $B$. burgdorferi chromosome (Davidson et al., 1992; Old et al., 1992a; Casjens \& Huang, 1993).
The results of this investigation indicate that the physical maps of the B. burgdorferi, B. garinii and B. afzelii chromosomes have few common features, but the genetic maps are strikingly similar. We interpret these observations to indicate that the divergent evolution of the chromosomes of these three species involved changes in their nucleotide sequences but no major rearrangements or inversions.

\section{METHODS}

Bacterial strains, plasmids and gene probes. B. burgdorferi strain 212, B. garinii strains 20047, Ir210, NBS16, NT29, PD89 and Sika1, and B. afzelii strains VS461, BO23, ECM1 and IPer3 (Baranton et al., 1992; Canica et al., 1993; Fukunaga et al., 1993), from the strain collection of the Institut Pasteur, were grown in BSKII medium (Barbour, 1984) as described previously for $B$. burgdorferi 212 (Davidson et al., 1992). The strains used for mapping studies were B. burgdorferi 212, B. garinii 20047 and B. afzelii VS461, and unless specified otherwise the terms $B$. burgdorferi, B. garinii and $B$. afzelii have been used throughout to refer to these three strains. Plasmids used as hybridization probes for genetic mapping studies are listed in Table 1 . The $p g k, t p i, p l s C, p a r E, d n a B$, gid $B, \operatorname{mox} \mathrm{R}, t \operatorname{mp} C$, , tp $G$, met $G$, mia $A$, $p t h$ and $f t s H$ genes were isolated and identified by sequencing of randomly chosen clones from a library of $B$. burgdorferi 212 DNA in pUC18 (Old et al., 1992a). All other genes used (see Table 1) were also from $B$. burgdorferi, with the exception of the p100 gene, which was from $B$. afzelii.

DNA preparations and mapping studies using pulsed-field gel electrophoresis (PFGE). The methods used for the preparation of high-molecular-mass genomic and chromosomal DNA in agarose blocks, DNA digestions, purification of DNA restriction fragments and two-dimensional PFGE experiments were those described previously (Davidson et al., 1992; Tulloch et al., 1991). The following techniques were used to elucidate physical maps of the chromosomes: double digests of highmolecular-mass chromosomal and genomic DNA, redigestion of PFGE-purified fragments with a second restriction endonuclease, and determination of the hybridization properties of fragments with a specific gene probe whose map location had been independently established. PFGE was performed in either a CHEF-DRII or a Chef Mapper apparatus (Bio-Rad). The borrelial DNA used as a template for the PCR was prepared from pelleted cells as described by Carniel et al. (1989).

Fragment nomenclature. Fragments produced by digestion of the chromosome by a single restriction endonuclease have been designated $\mathrm{Sg}, \mathrm{Ce}, \mathrm{Sm}, \mathrm{Ea}, \mathrm{Bs}, \mathrm{Ml}, \mathrm{Ap}, \mathrm{Cs}$, or Sc to identify the enzyme [SgrAI, I-CeuI, SmaI, EagI, BssHII, MluI, ApaI, CspI, or SacII (KspI), respectively], with a capital letter suffix, A or B, etc. in the order of decreasing fragment size (Table 2). For fragments indistinguishable in size, the suffix is numbered 1 or 2 , etc., e.g. $\mathrm{ApB} 1$ and ApB2. Fragments produced by digestion with two restriction endonucleases have been designated by the two single-digest fragments from which they were derived, e.g. $\mathrm{SmC}-\mathrm{ApB} 1$ contains DNA from the overlapping region of SmC and $A p B 1$.

PCR. Specific primers (Table 3), designed to amplify part of the borrelial rRNA gene cluster, were synthesized on a model $381 \mathrm{~A}$ DNA synthesizer (Applied Biosystems). The PCR was carried out in a model FTS-1C thermal cycler (Corbett-Research) with Taq DNA polymerase (Perkin Elmer-Cetus), using buffers supplied by Perkin Elmer-Cetus, $250 \mathrm{ng}$ of each primer, and 
Table 1. Hybridization of gene probes with B. garinii 20047 and B. afzelii VS461 chromosome fragments

\begin{tabular}{|c|c|c|c|c|c|c|c|}
\hline \multirow[t]{2}{*}{ Gene(s) } & \multirow{2}{*}{$\begin{array}{l}\text { Plasmid/ } \\
\text { probe }\end{array}$} & \multirow[t]{2}{*}{ Gene product(s) } & \multirow{2}{*}{$\begin{array}{l}\text { Reference/ } \\
\text { source }\end{array}$} & \multicolumn{2}{|c|}{ B. garinii } & \multicolumn{2}{|c|}{ B. afzelii } \\
\hline & & & & $\begin{array}{l}\text { Hybridizing } \\
\text { fragments* }\end{array}$ & $\begin{array}{l}\text { Map } \\
\text { location } \\
(\mathrm{kbp})\end{array}$ & $\begin{array}{l}\text { Hybridizing } \\
\text { fragments* }\end{array}$ & $\begin{array}{c}\text { Map } \\
\text { location } \\
\text { (kbp) }\end{array}$ \\
\hline$p g k$ tpi & $\mathrm{pB} 45$ & $\begin{array}{l}\text { Phosphoglycerate kinase, triose } \\
\text { phosphate isomerase }\end{array}$ & GenBank L32595 & $\mathrm{BsD}$ & $0-90$ & ND & ND \\
\hline plsc parE & pB38 & $\begin{array}{l}\text { 1-Acyl-sn-glycerol-3-phosphate } \\
\text { acetyltransferase, B-subunit of } \\
\text { topoisomerase IV }\end{array}$ & GenBank L32861 & $\mathrm{BsD}$ & $0-90$ & $\mathrm{SmD}$ & $0-118$ \\
\hline$d n a B$ & pB54 & DnaB & $\begin{array}{l}\text { D. Margarita \& } \\
\text { I. Old } f\end{array}$ & $\mathrm{MlC}$ & $0-135$ & $\mathrm{SmD}, \mathrm{ApA}$ & $27-118$ \\
\hline$f a$ & pARA1 & Flagellin & $\begin{array}{l}\text { Gassmann et al. } \\
\text { (1991) }\end{array}$ & ApB1 & $151-165$ & $\mathrm{Sm} A, \mathrm{Cs} B$ & $118-209$ \\
\hline gid' $f^{\prime}$ & $\mathrm{pB} 4$ & $\begin{array}{l}\text { Glucose-inhibited division } \\
\text { protein }\end{array}$ & Old et al. (1992a) & ApB1 & $184-241$ & $\mathrm{Sm} A, \mathrm{CsB}$ & $118-209$ \\
\hline $\begin{array}{l}\operatorname{gid}^{\prime} A B \\
\operatorname{mox} \cdot R^{\prime}\end{array}$ & pB43 & $\begin{array}{l}\text { Glucose-inhibited division } \\
\text { proteins, regulator for } \\
\text { methanol dehydrogenase }\end{array}$ & $\begin{array}{l}\text { D. Margarita \& } \\
\text { I. Old } \dagger\end{array}$ & ApB1 & $184-241$ & $\mathrm{Sm} A, \mathrm{CsB}$ & $118-209$ \\
\hline rbo & PCR product & $\begin{array}{l}\text { Transcription termination factor } \\
\text { rho }\end{array}$ & $\begin{array}{l}\text { Tilly \& Campbell } \\
\text { (1993) }\end{array}$ & $\mathrm{SmA}, \mathrm{ApH} 2$ & $241-264$ & $\mathrm{SmA}$ & $118-269$ \\
\hline $\operatorname{fgE}$ & M13DNAflgE & Flagellar hook protein & $\begin{array}{l}\text { N. Charon, West } \\
\text { Virginia University, } \\
\text { USA }\end{array}$ & $\mathrm{SgB}-\mathrm{ApE} 2$ & $264-316$ & $\mathrm{ApB}, \mathrm{SmC}$ & $278-398$ \\
\hline$f i G$ & $\mathrm{pB} 30$ & Flagellar shift protein & $\begin{array}{l}\text { D. Margarita \& } \\
\text { I. Old } \dagger\end{array}$ & $\begin{array}{l}\mathrm{SgA}, \mathrm{SgB} \\
\mathrm{ApE} 2\end{array}$ & $315-317$ & $\mathrm{ApB}, \mathrm{SmC}$ & $278-398$ \\
\hline$f t s, A \%$ & $\mathrm{pB} 29$ & Cell division proteins & Old et al. (1992a) & ApE2 & $316-326$ & $\mathrm{ApB}, \mathrm{SmC}$ & $278-398$ \\
\hline p 60 gene & pHMB35 & $60 \mathrm{kDa}$ antigen & $\begin{array}{l}\text { Howe et al. } \\
\text { (1985) }\end{array}$ & $\mathrm{ApC} 2$ & $326-408$ & ND & ND \\
\hline $\operatorname{tmp} c$ & $\mathrm{pB} 46$ & Membrane lipoprotein & $\begin{array}{l}\text { D. Margarita \& } \\
\text { I. Old } \dagger\end{array}$ & $\mathrm{SmA}, \mathrm{ApC} 2$ & $326-408$ & ND & ND \\
\hline $\operatorname{rr} / A B$ & $\begin{array}{l}\text { CO1-CO6 } \\
\text { PCR product }\end{array}$ & $3^{\prime}$ end of $23 \mathrm{~S}$ rRNA & This work & $\begin{array}{l}\mathrm{SmA}, \mathrm{SmF} \\
\mathrm{MlG}\end{array}$ & $456-463$ & $\begin{array}{l}\text { SmL, SmI } \\
\text { or SmJ }\end{array}$ & $461-468$ \\
\hline $\operatorname{rr} l A B$ & $\begin{array}{l}\text { CO8-CO9 } \\
\text { PCR product }\end{array}$ & $5^{\prime}$ end of $23 \mathrm{~S}$ rRNA & This work & SmF, SmG & $456-463$ & $\begin{array}{l}\text { SmI, SmK- } \\
\text { MIA }\end{array}$ & $461-468$ \\
\hline rrs & $\begin{array}{l}\mathrm{CO} 4 \mathrm{CO} 5 \\
\text { PCR product }\end{array}$ & $3^{\prime}$ end of $16 S$ rRNA & This work & SmD-MIG & $468-469 \ddagger$ & $\begin{array}{l}\text { SmK } \\
\text { MIA }\end{array}$ & $473-474 \ddagger$ \\
\hline gyr'B.1 & $\mathrm{pB} 3$ & $\begin{array}{l}\text { B-and A-subunits of DNA } \\
\text { gyrase }\end{array}$ & Old et al. (1992a) & $\mathrm{EaE}, \mathrm{MlF}$ & $469-520$ & SmK, MID & $482-488 \rrbracket$ \\
\hline $\begin{array}{l}\operatorname{gyr} B^{\prime} \\
\operatorname{dna} A \Upsilon \\
\operatorname{rpm} H \\
\operatorname{rnp} A\end{array}$ & $\mathrm{pB} 22$ & $\begin{array}{l}\text { B-subunit of DNA gyrase, } \\
\text { DNA replication proteins, } \\
\text { ribosomal protein L } 34, \\
\text { ribonuclease P (protein } \\
\text { component) }\end{array}$ & $\begin{array}{l}\text { Old et al. (1992b, } \\
\text { 1993a, b); Saint } \\
\text { Girons et al. } \\
(1994)\end{array}$ & EaE, MIF & $469-520$ & $\mathrm{SmE}, \mathrm{EaC}$ & $488-492 \S$ \\
\hline phest & pBDP218 & $\begin{array}{l}\alpha \text { - and } \beta \text {-subunits of } \\
\text { phenylalanyl-tRNA synthetase }\end{array}$ & $\begin{array}{l}\text { J. Hinnebusch \& } \\
\text { A. Barbour, } \\
\text { University of Texas } \\
\text { Health Science } \\
\text { Center, USA }\end{array}$ & MID, ApC1 & $542-616$ & SmE, MIC & $529-566$ \\
\hline $\begin{array}{l}d n a J \\
d n a K\end{array}$ & pKK11 & Heat-shock proteins & Tilly et al. (1993) & $\mathrm{MlD}, \mathrm{ApC1}$ & $542-616$ & $\mathrm{MlC}$ & $529-613$ \\
\hline$b t p G$ & $\mathrm{pB} 25$ & Heat-shock protein & GenBank L32145 & MlD, ApC1 & $542-616$ & $\mathrm{SmH}$ & $566-612$ \\
\hline$P C R$ & $\mathrm{pB} 2$ & PCR target & $\begin{array}{l}\text { Old et al. (1992a); } \\
\text { Rosa et al. (1991) }\end{array}$ & $\mathrm{SmE}, \mathrm{EaC}$ & $627-698$ & $\mathrm{ND}$ & ND \\
\hline $\operatorname{met} G$ & $\mathrm{pB} 7$ & Methionyl-tRNA synthetase & GenBank L32146 & $\mathrm{SmE}, \mathrm{EaC}$ & $627-698$ & $\mathrm{ND}$ & ND \\
\hline$g r o E L$ & $\mathrm{pKH} 317$ & Heat-shock proteins & $\begin{array}{l}\text { Hansen et al. } \\
\text { (1988) }\end{array}$ & $\mathrm{SgA}, \mathrm{ApE} 1$ & $706-728$ & $\mathrm{SmB}$ & $686-824$ \\
\hline p100 gene & $\mathrm{p} 100$ & $100 \mathrm{kDa}$ antigen & $\begin{array}{l}\text { Jauris-Heipke } e t \\
\text { al. (1993) }\end{array}$ & MIB, ApA & $823-843$ & $\mathrm{SmF} 2$ & $824-898$ \\
\hline ptb ftsH & pB15 & $\begin{array}{l}\text { Peptidyl-tRNA hydrolase, cell } \\
\text { division protein }\end{array}$ & $\begin{array}{l}\text { D. Margarita \& } \\
\text { I. Old } \dagger\end{array}$ & MlE & $843-923$ & $\mathrm{SmF} 2$ & $824-898$ \\
\hline $\operatorname{mia} A$ & $\mathrm{pB} 5$ & $\begin{array}{l}\text { 2-Methyithio-N6- } \\
\text { isopentyladenosine } \\
\text { hypermodification of tRNA }\end{array}$ & $\begin{array}{l}\text { D. Margarita \& } \\
\text { I. Old } \dagger\end{array}$ & MIE & $843-923$ & $\mathrm{SgB}, \mathrm{SmG}$ & $898-936$ \\
\hline
\end{tabular}

ND, Not determined.

* Only the minimum number of fragments that define the gene location are listed.

† Unpublished results; $t m p C$ corresponds to p39 (Casjens \& Huang, 1993).

$\ddagger$ Precise location was established from the MluI site in the $16 \mathrm{~S}$ rRNA sequence (Marconi \& Garon, 1992a).

\Precise locations of gyrB $A$ and dna $A N$ rpmH $m p A$ were established from a deduced $S m a$ l site in $B$. afzelii dnaA. 
Table 2. Endonuclease fragments of the chromosomes of B. garinii 20047 and B. afzelii VS461

The lower limit of fragment size detected was $1.4 \mathrm{kbp}$. Adjusted val ues (Adj) are the observed values after corrections to give chromosome sizes of 953 and $948 \mathrm{kbp}$ for B. garinii and B. afzelii, respectively, and after minor adjustments to fit fragments into the map. ND, Not determined.

\begin{tabular}{|c|c|c|c|c|c|c|c|c|c|c|c|c|c|c|c|c|c|c|}
\hline \multirow[t]{3}{*}{ Fragment } & \multicolumn{18}{|c|}{ Mean size $(k b p)$ of fragment generated by: } \\
\hline & \multicolumn{2}{|l|}{ CspI } & \multicolumn{2}{|c|}{ SgrAI } & \multicolumn{2}{|l|}{ SacII } & \multicolumn{2}{|l|}{$\mathrm{I}-C_{e u \mathrm{I}}$} & \multicolumn{2}{|c|}{ Smal } & \multicolumn{2}{|c|}{ EagI } & \multicolumn{2}{|c|}{ Bss HII } & \multicolumn{2}{|c|}{$M l u \mathrm{I}$} & \multicolumn{2}{|c|}{ Apa $\mathrm{I}^{*}$} \\
\hline & Observed & Adj & Observed & Adj & Observed & Adj & Observed & Adj & Observe & Adj & Observed & Adj & Observed & Adi & Observed & Ad $j$ & Observed & Adj \\
\hline \multicolumn{19}{|l|}{ B. gariniit } \\
\hline$A$ & & & 400 & 412 & ND & & 493 & 493 & 275 & 274 & 460 & 457 & 278 & 278 & 280 & 278 & 130 & 130 \\
\hline B & & & 310 & 316 & & & 458 & 457 & 255 & 251 & 190 & 185 & 260 & 255 & 230 & 219 & $90 \neq$ & 90 \\
\hline$c$ & & & 220 & 225 & & & $3 \cdot 2$ & 3 & 182 & 184 & 180 & 178 & 184 & 192 & 140 & 135 & $80 \ddagger$ & 82 \\
\hline D) & & & & & & & & & 153 & 164 & 70 & 70 & 90 & 90 & 85 & 82 & $70 \neq$ & 70 \\
\hline $\mathrm{E}:$ & & & & & & & & & 75 & 75 & 60 & 60 & 75 & 75 & 80 & 80 & $62 \ddagger$ & 62 \\
\hline $\mathrm{F}$ & & & & & & & & & $3 \cdot 2$ & 3 & $3 \cdot 2$ & 3 & 37 & 37 & 60 & 59 & 55 & 55 \\
\hline G & & & & & & & & & 1.8 & 2 & & & 23 & 23 & 54 & 56 & & \\
\hline $\mathrm{H}$ & & & & & & & & & & & & & $3 \cdot 2$ & 3 & 34 & 30 & 23 & 23 \\
\hline I & & & & & & & & & & & & & & & 15 & 14 & & \\
\hline Total & & & 930 & 953 & & & 954 & 953 & 945 & 953 & 963 & 953 & 950 & 953 & 978 & 953 & & \\
\hline \multicolumn{19}{|l|}{ B. afzelii } \\
\hline$A$ & 750 & 739 & 750 & 743 & 474 & 474 & 485 & 483 & 151 & 151 & 463 & 462 & 485 & 483 & 468 & 474 & 202 & 200 \\
\hline H & 209 & 209 & 193 & 193 & 389 & 387 & 460 & 462 & 138 & 138 & 437 & 428 & 458 & 462 & 356 & 335 & 157 & 155 \\
\hline$c$ & & & 12 & 12 & 88 & 87 & $3 \cdot 2$ & 3 & 129 & 129 & 56 & 55 & $3 \cdot 2$ & 3 & 86 & 84 & 113 & \\
\hline D) & & & & & & & & & 118 & 118 & 3.2 & 3 & & & 56 & 55 & 104 & \\
\hline $\mathrm{E}$ & & & & & & & & & 78 & 78 & & & & & & & 61 & \\
\hline $\mathrm{F}$ & & & & & & & & & $74 \ddagger$ & 74 & & & & & & & 57 & \\
\hline$G$ & & & & & & & & & $50^{\top}$ & 50 & & & & & & & 53 & \\
\hline $\mathrm{H}$ & & & & & & & & & 46 & 46 & & & & & & & 51 & 51 \\
\hline 1 & & & & & & & & & 34 & 34 & & & & & & & 43 & \\
\hline J & & & & & & & & & 30 & 30 & & & & & & & 40 & 40 \\
\hline$k$ & & & & & & & & & 23 & 23 & & & & & & & 27 & 27 \\
\hline$L$ & & & & & & & & & $3 \cdot 2$ & 3 & & & & & & & 23 & 23 \\
\hline $\mathrm{M}$ & & & & & & & & & & & & & & & & & 15 & \\
\hline$N$ & & & & & & & & & & & & & & & & & 10 & \\
\hline Total & 959 & 948 & 955 & 948 & 951 & 948 & 948 & 948 & 948 & 948 & 959 & 948 & 946 & 948 & 966 & 948 & 956 & \\
\hline
\end{tabular}

* List of fragments is incomplete for B. garinii.

† The B. garinii chromosome was not digested by $C s p$ I.

$\ddagger$ Relative staining intensities indicated the presence of two of each of the B. garinii ApaI fragments of $90,80,70$ and $62 \mathrm{kbp}$, and two B. af $Z$ elii SmaI fragments of $74 \mathrm{kbp}$.

$30-100 \mathrm{ng}$ template DNA in a final volume of $50 \mu \mathrm{l}$. The reactions were repeated for 35 cycles with a profile of $1 \mathrm{~min}$ at $95^{\circ} \mathrm{C}, 1 \mathrm{~min}$ at $43^{\circ} \mathrm{C}$ and $1 \mathrm{~min}$ at $72^{\circ} \mathrm{C}$. A $10 \mu \mathrm{l}$ sample of the products was analysed by electrophoresis through agarose in

Table 3. Oligonucleotides used as PCR primers for rRNA. gene amplification

\begin{tabular}{|llcc|}
\hline Oligonucleotide & Sequence & $\begin{array}{c}\text { rRNA } \\
\text { gene }\end{array}$ & $\begin{array}{c}\text { Position } \\
\text { in } \\
\text { sequence* }\end{array}$ \\
& & & \\
\hline CO1 & AGGACCGAGATGGAC & $r r l$ & $2701-2716$ \\
CO2 & CTTAAAGCTCCTAGGC & $r r l$ & $45-30$ \\
CO3 & ATAACCTACTCTCCCG & $r r f$ & $104-89$ \\
CO4 & CAAATCATCATGGCC & $r r s$ & $1188-1213$ \\
CO5 & ATAGCTTCGGGATTCC & $r r s$ & $1432-1417$ \\
CO6 & TGGCCAAAGATACGG & $r r l$ & $2925-29: 0$ \\
CO7 & GGTTAAAGAAAAGAGG & $r r f$ & $5-20$ \\
CO8 & GAAGGTGATAGTCCTGT & $r r l$ & $393-409$ \\
CO9 & CTCTTCTCTATCGGTAG & $r r l$ & $531-515$ \\
\hline
\end{tabular}

* From Schwartz et al. (1992).
TBE (TBE is $89 \mathrm{mM}$ Tris, $89 \mathrm{mM}$ borate and $2 \mathrm{mM}$ EDTA, $\mathrm{pH} 8 \cdot 0)$.

Southern blots and DNA hybridizations. Southern blots were prepared by the procedure of transfer with depurination (Reed \& Mann, 1985), using nylon membranes (Hybond $\mathrm{N}+$, Amersham). ${ }^{32} \mathrm{P}$ - and digoxigenin-labelled DNA probes were obtained by random priming (Feinberg \& Vogelstein, 1984) using commercial kits (Boehringer Mannheim). Membranes were prehybridized with a solution containing $0.5 \%(\mathrm{w} / \mathrm{v})$ SDS, $5 \times$ Denhardt's solution $(1 \times$ Denhardt's solution is $0.02 \%, \mathrm{w} / \mathrm{v}$, bovine serum albumin, $0.02 \%$, w/v, Ficoll, and $0.02 \%, \mathrm{w} / \mathrm{v}$, polyvinylpyrrolidone $)$, and $5 \times \mathrm{SSPE}(1 \times \mathrm{SSPE}$ is $36 \mathrm{mM} \mathrm{NaCl}, 2 \mathrm{mM} \mathrm{Na}{ }_{2} \mathrm{HPO}_{4}$ and $1 \mathrm{mM}$ EDTA, pH 7.4). After hybridization with the probe at $60{ }^{\circ} \mathrm{C}$ for $18 \mathrm{~h}$, the final stringent wash of the membrane was performed in $0.1 \times \mathrm{SSPE}$ containing $0 \cdot 1 \%(\mathrm{w} / \mathrm{v})$ SDS for $15 \mathrm{~min}$ at $65^{\circ} \mathrm{C}$.

\section{RESULTS}

Restriction digestion and estimation of the sizes of the $B$. garinii and $B$. afzelii chromosomes

PFGE of undigested high-molecular-mass DNA from $B$. garinii or $B$. afzelii yielded a band with a mobility typical of 
(a)

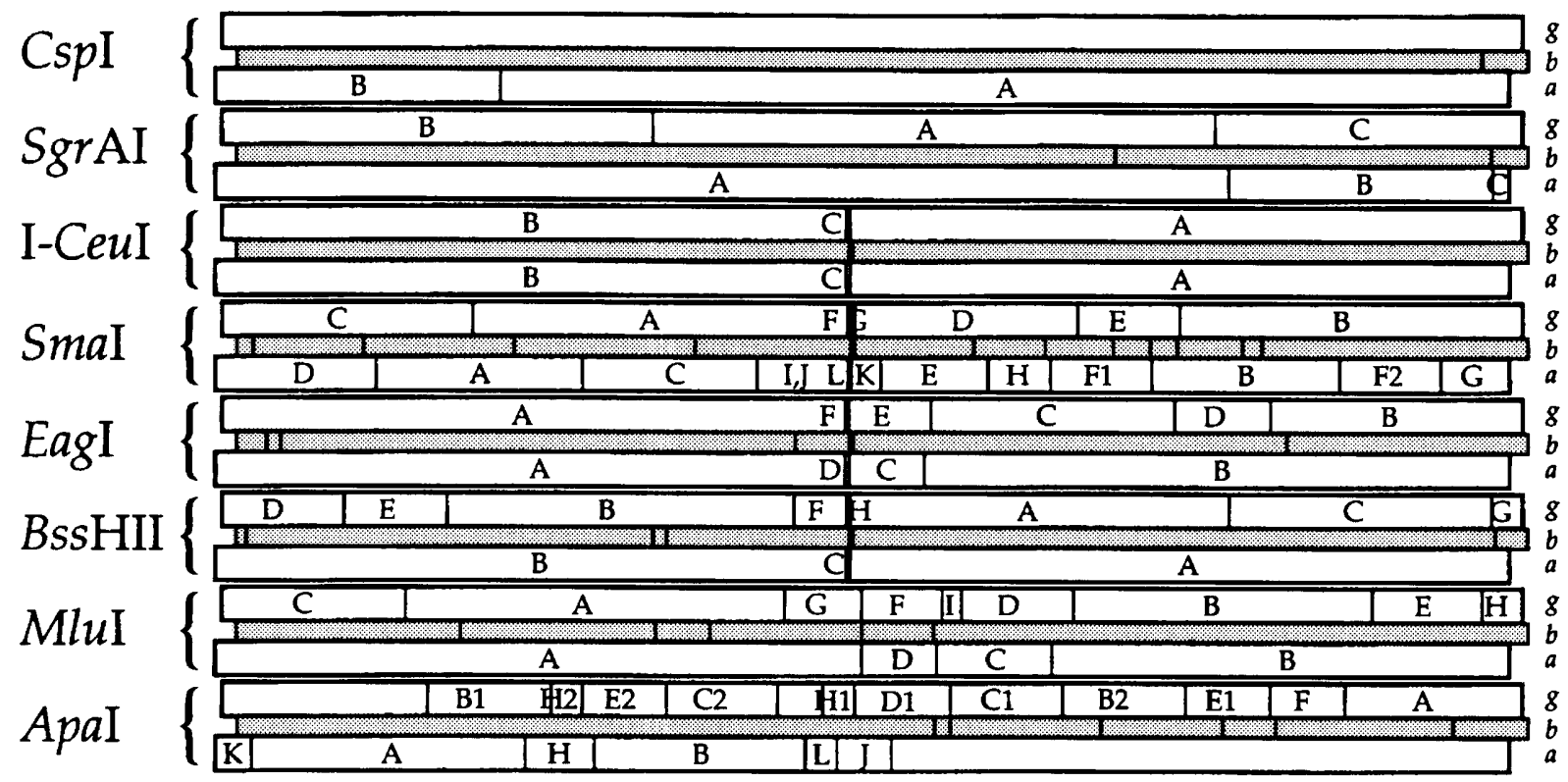

(b)

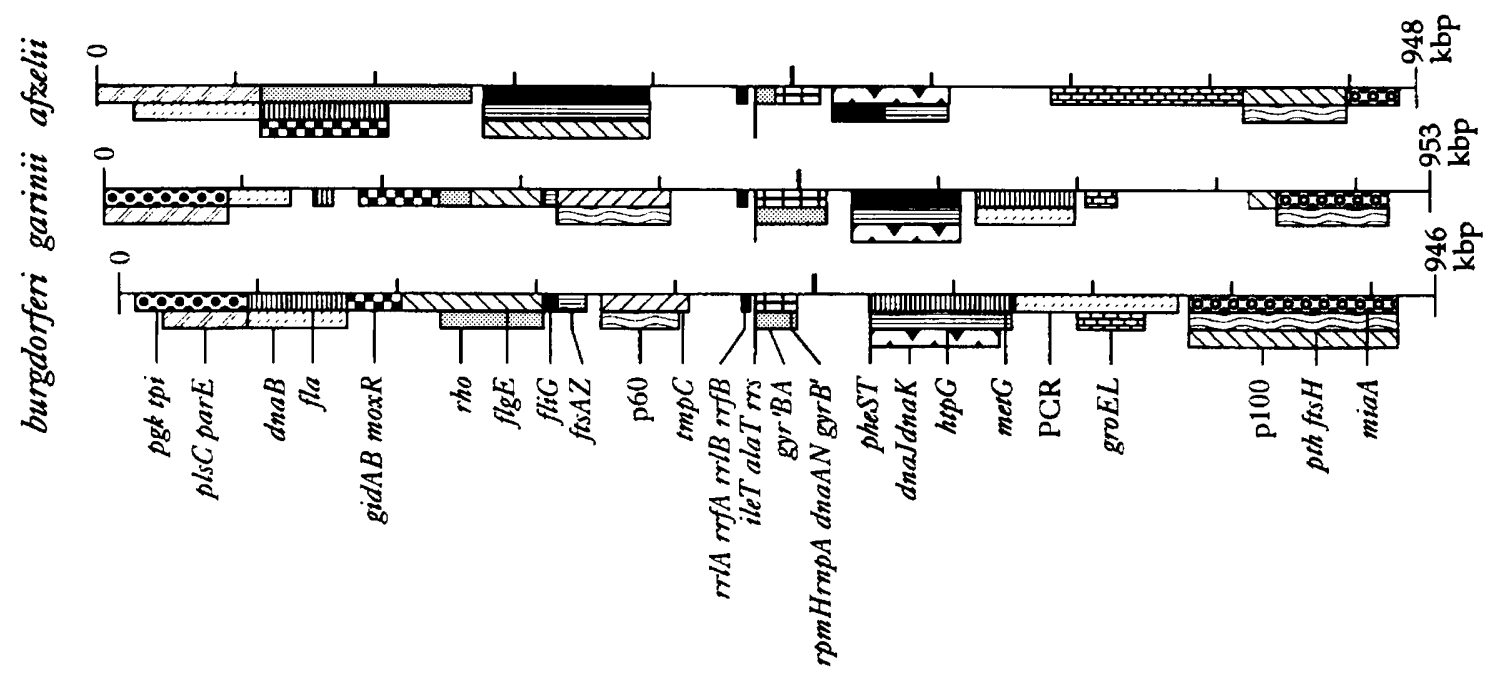

Fig. 1. Maps of the chromosomes of B. garinii 20047, B. burgdorferi 212 and B. afzelii VS461. (a) Physical maps. For each enzyme, the $B$. garinii map is represented at the top by open boxes, the $B$. burgdorferi map (Davidson et al., 1992; Cspl and I-Ceul sites mapped in this study) is represented in the middle by shaded boxes, and the $B$. afzelii map is represented at the bottom by open boxes. The three maps have been aligned by the centrally located Mlul site in rrs. Fragments are designated A, B, etc. Only some of the Apal sites and fragments are included in each map. (b) Genetic maps. Fill patterns for individual genes or gene clusters are the same in all three maps, with the $B$. burgdorferi map providing the key for the correspondence between specific fill pattern and gene/gene cluster. The genes ala $T$ and ile $T$ were not mapped for $B$. garinii and $B$. afzelii, while $p g k, t p i, t m p C$, metG, PCR and the p60 gene were not mapped for $B$. afzelii.

a linear $1 \mathrm{Mbp}$ DNA molecule, as reported previously (e.g. see Fig. 1a, lane 11 of Baril et al., 1989). This $1 \mathrm{Mbp}$ species was presumed to be the linear chromosome. Fragments of $<100 \mathrm{kbp}$, which were probably plasmids, were also seen. Endonucleases having GC-rich recognition sites (SgrAI, I-CeuI, SmaI, MluI, BssHII, EagI and $A p a \mathrm{I})$ were found to cut the two chromosomes into a useful number of fragments for mapping studies (Table 2). SacII and CspI were also used for mapping B. afzelii (CspI did not digest the B. garinii chromosome). As was found previously with $B$. burgdorferi (Davidson et al., 1992), the presence of the plasmids complicated the digestion patterns obtained with high-molecular-mass genomic DNA from $B$. garinii and $B$. afzelii. The uncertainties in interpretation of the patterns were avoided by first isolating high-molecular-mass chromosomal DNA in agarose by PFGE, then digesting this DNA. The sum of the fragment sizes produced by each enzyme yielded estimates for the size of the two chromosomes (Table 2). For B. garinii, the mean value of 
$953 \mathrm{kbp}$ for the first six enzymes was used as the chromosome size in the construction of the restriction map. For B. afzelii, each of the enzymes that was used for making a full map yielded only a few large fragments, with the exception of $S m a \mathrm{I}$. Because of this it was considered most reliable to use the sum of sizes of the SmaI fragments only (948 kbp) for an estimate of the size of the B. afzelii chromosome.

\section{Physical and genetic maps of the B. garinii and $B$. afzelii chromosomes}

Physical maps of the B. garinii and B. afzelii chromosomes (Fig. 1a) were elucidated as described in Methods. The maps contain 42 digestion sites for $B$. garinii and 32 for $B$. afzelii (Table 4). A comparison of these maps with that of the B. burgdorferi chromosome (Fig. 1a) reveals few common sites in the three chromosomes, with the striking exception of a cluster of sites near the centre of each map. Analyses, presented below, indicated that these sites are located in the rRNA genes, loci that are both GC-rich and highly conserved. The similar location of certain other sites in two of the three species suggested limited conservation of these sites. Specifically, these were the BssHII sites at map coordinates 921 and 930 in $B$. burgdorferi and $B$. garinii, respectively; the $A p a \mathrm{I}$ sites at map coordinates 523 and 534 in B. burgdorferi and $B$. garinii, respectively; and three pairs of $S \mathrm{mal}$ sites (at map coordinates 689 and 702 in B. burgdorferi and B. garinii, map coordinates 669 and 686 in B. burgdorferi and B. afzelii, and map coordinates 592 and 612 in B. burgdorferi and $B$. af zelii).

The physical maps were used for constructing genetic maps. To do this, probes containing borrelial genes (Table 1) were hybridized with Southern blots of gel separations of restriction digests of B. burgdorferi, B. garinii and $B$. afzelii DNA to identify the restriction fragment that carried the gene. Using this approach, genetic maps were determined for the first time for $B$. garinii and $B$. afzelii and our previously reported genetic map of $B$. burgdorferi 212 (Old et al., 1992a) was expanded from 14 to 41 loci (Fig. 1b). Nineteen of these 41 genes on the $B$. burgdorferi map ( $f a, r b o, f g E, r r l A, r r l B, r r f A, r r f B, r r s$, alaT, dna N, dna $A, \operatorname{gyr} B, \operatorname{gyr} A$, pheS, phe T, dnaJ, dnak, groEL and the p100 gene) have also been mapped on an American isolate of $B$. burgdorferi, Sh-2-82 (Casjens \& Huang, 1993). Each of these genes was found to occupy the same position in the genome of both isolates, within the limits of precision of the mapping experiments.

The genetic maps of the chromosomes of the three different Lyme disease spirochaetes contain 41 loci for $B$. burgdorferi, 39 for B. garinii and 33 for B. afzelii (Fig. 1b). The uneven and different distributions of endonuclease sites along each of the chromosomes result in large dissimilarities in the resolution of the genetic maps for the same region of each chromosome. Although these dissimilarities complicate the comparison of the three maps, it is clear that the mapping studies provide no indication of any differences in the gene order of the chromosomes of the three species (Fig. 1b).
Table 4. Map locations of endonuclease sites in the $B$. garinii 20047 and B. afzelii VS461 chromosomes

The map coordinates are based on the sizes of single-digestion products (Table 2) and double-digestion products (data not shown).

\begin{tabular}{|c|c|c|c|}
\hline \multicolumn{2}{|c|}{ B. garinii } & \multicolumn{2}{|c|}{ B. afzelii } \\
\hline Endonuclease & $\begin{array}{c}\text { Map } \\
\text { coordinate } \\
\text { of site } \\
\text { (kbp) }\end{array}$ & Endonuclease & $\begin{array}{c}\text { Map } \\
\text { coordinate } \\
\text { of site } \\
\text { (kbp) }\end{array}$ \\
\hline$B s s \mathrm{HII}$ & 90 & ApaI & 27 \\
\hline MluI & 135 & SacII & 87 \\
\hline$A p a \mathrm{I}$ & 151 & $S m a I$ & 118 \\
\hline BssHII & 165 & CspI & 209 \\
\hline$S m a \mathrm{I}$ & 184 & $A p a \mathrm{I}$ & 227 \\
\hline$A p a \mathrm{I}$ & 241 & SmaI & 269 \\
\hline ApaI & 264 & $A p a \mathbf{I}$ & 278 \\
\hline SgrAI & 316 & Smal & 398 \\
\hline$A p a \mathrm{I}$ & 326 & ApaI & 433 \\
\hline$A p a \mathrm{I}$ & 408 & ApaI & 456 \\
\hline$M l u \mathrm{I}$ & 413 & EagI & 462 \\
\hline$B s s \mathrm{HII}$ & 420 & $\mathrm{I}-C e u \mathrm{I}$ & 463 \\
\hline$A p a \mathrm{I}$ & 441 & BssHII & 463 \\
\hline EagI & 457 & $S m a I$ & 464 \\
\hline $\mathrm{I}-C e u \mathrm{I}$ & 458 & EagI & 465 \\
\hline BssHII & 458 & $\mathrm{I}-C e u \mathrm{I}$ & 466 \\
\hline$S m a \mathrm{I}$ & 459 & $B s s \mathrm{HII}$ & 466 \\
\hline EagI & 460 & $S m a \mathbf{I}$ & 467 \\
\hline $\mathrm{I}-C_{e u \mathrm{I}}$ & 461 & SacII & 474 \\
\hline BssHII & 461 & $M l u \mathrm{I}$ & 474 \\
\hline SmaI & 462 & SmaI & 488 \\
\hline SmaI & 464 & $A p a \mathrm{I}$ & 496 \\
\hline$A p a \mathrm{I}$ & 464 & EagI & 520 \\
\hline$M l u \mathrm{I}$ & 469 & $M l u \mathrm{I}$ & 529 \\
\hline EagI & 520 & $S m a \mathrm{I}$ & 566 \\
\hline$M / u \mathrm{I}$ & 528 & SmaI & 612 \\
\hline ApaI & 534 & $M l u \mathrm{I}$ & 613 \\
\hline$M l u \mathrm{I}$ & 542 & SmaI & 686 \\
\hline ApaI & 616 & SgrAI & 743 \\
\hline$M l u \mathrm{I}$ & 624 & $S m a I$ & 824 \\
\hline SmaI & 627 & $S m a I$ & 898 \\
\hline EagI & 698 & SgrAI & 936 \\
\hline$S m a I$ & 702 & & \\
\hline ApaI & 706 & & \\
\hline SgrAI & 728 & & \\
\hline BssHII & 738 & & \\
\hline EagI & 768 & & \\
\hline Apa $\mathrm{I}$ & 768 & & \\
\hline ApaI & 823 & & \\
\hline$M l u \mathrm{I}$ & 843 & & \\
\hline$M l u \mathrm{I}$ & 923 & & \\
\hline BssHII & 930 & & \\
\hline
\end{tabular}

\section{High resolution mapping around the IRNA gene loci in B. garinii and B. afzelii}

In view of the close similarity of the genetic maps it was 
decided to use higher resolution mapping to analyse a short segment of the chromosome in more detail. The region containing the rRNA genes was chosen for this analysis since the number and arrangement of rRNA genes in $B$. burgdorferi is unique among eubacteria (Davidson et al., 1992; Schwartz et al., 1992; Fukunaga \& Sohnaka, 1992). The B. burgdorferi chromosome has a single copy of $\mathrm{rrs}$, separated by $2.7 \mathrm{kbp}$ from a tandem duplication containing two copies each of $r r l$ and $r r f$ (Fig. 2a). Specific probes for $r r l$, rrs and $r r f$ were made by PCR using $\mathrm{CO} 1-\mathrm{CO}$, $\mathrm{CO} 4-\mathrm{CO} 5$ and $\mathrm{CO} 3-\mathrm{CO} 7$, respectively, as amplimer pairs (Fig. 2a). B. burgdorferi DNA was used as the template DNA for the PCR.

rRNA gene copy numbers. The rrs probe hybridized with one $M / u \mathrm{I}$ fragment (M1G for B. garinii and M1A for $B$. afzelii) and one $\mathrm{HpaI}$ fragment (of $7 \mathrm{kbp}$ for B. garinii and $2 \mathrm{kbp}$ for B. afzelii) in Southern blots prepared from digests of B. garinii and B. afzelii DNA. Since there is only one site each for $M l u \mathrm{I}$ and $\mathrm{H} p a \mathrm{I}$ in the reported $B$. garinii and $B$. afzelii $16 \mathrm{~S} \mathrm{rRNA}$ sequences [strains G1 (Marconi \& Garon, 1992a) and R-IP3 (Marconi \& Garon, 1992b), respectively], this observation established the presence of a single copy of rrs in both the B. garinii and B. afzelii chromosomes.

The $r r l$ and $r r f$ probes behaved identically when hybridized with Southern blots. With digests of the $B$. garinii chromosome, each probe hybridized to two HpaI fragments (of 1.7 and $3.2 \mathrm{kbp}$ ) and two $S \mathrm{maI}$ fragments (SmA and $\mathrm{SmF}$ ). A similar result was obtained with digests of $B$. afzelii DNA, where hybridization occurred with HpaI fragments of 4.0 and $3.2 \mathrm{kbp}$ and $S m a \mathrm{I}$ fragments SmL and SmI (or SmJ). These observations were consistent with the presence of two copies each of $\mathrm{rrl}$ and $r r f$ in the chromosomes of both organisms.

Juxtaposition of $\boldsymbol{r r}$ and $\boldsymbol{r} \boldsymbol{r}$. The juxtaposition of the $\boldsymbol{r r l}$ and $r r f$ genes in B. garinii and B. afzelii was determined by PCR with the amplimer pair CO1-CO3. PCR with these primers and $B$. burgdorferi DNA as template yielded a product of 350-355 bp, the size expected from the known juxtaposition of $r r l$ and $r r f$ in this organism (Fig. 2a). PCR products of a similar size were obtained with the same amplimer pair when either B. garinii or B. afzelii DNA was used as template. These observations indicated that the juxtaposition of $r r l$ and $r r f$ in $B$. garinii and B. afzelii was identical to that in B. burgdorferi (Fig. 2b).

Tandem duplication of $\boldsymbol{r r}$. The possibility that two copies of $r r l$ were present in a tandem duplication in the $B$. garinii and $B$. afzelii chromosomes was explored by carrying out PCR with $\mathrm{CO} 1-\mathrm{CO} 2$ as amplimers. With $B$. burgdorferi DNA as template a single product of $586 \mathrm{bp}$ was obtained. This product was of the size expected from the reported sequence (Schwartz et al., 1992) for amplification from the $3^{\prime}$ end of $\operatorname{rrl} A$ through $\operatorname{rrf} A$ into the $5^{\prime}$ end of $r r l B$ (Fig. 2a), and was indicative of one or more tandem duplications of $r r l$ genes. Identically sized PCR products were obtained when either $B$. garinii or $B$. afzelii DNA was used as template with CO1-CO2, indicating that the rRNA genes were also tandemly

(a)

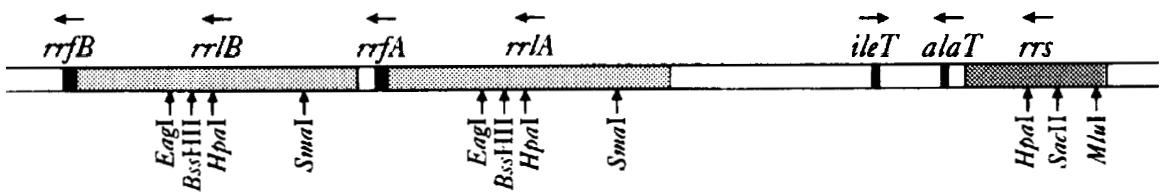

14

$16 \mathrm{kbp}$

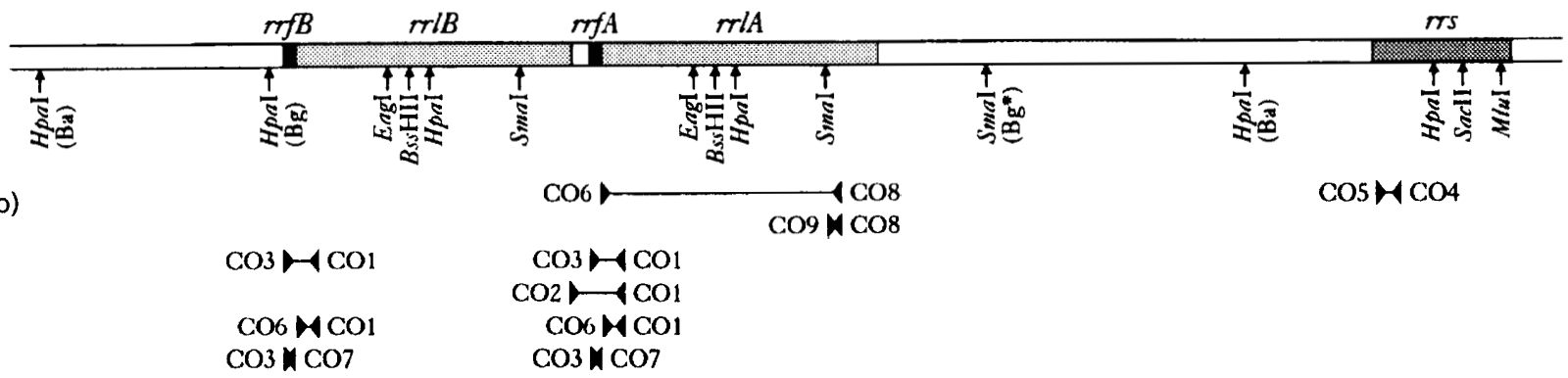

Fig. 2. Maps of the rRNA genes and intervening DNA of (a) B. burgdorferi and (b) $B$. garinii and $B$. afzelii. The $B$. burgdorferi map was derived from published data (Davidson et al., 1992; Schwartz et al., 1992; Gazumyan et al., 1994). For the B. garinii and B. afzelii maps, sites were located as follows: Sacll sites, from the sequences of $B$. garinii $G 1$ and $B$. afzelii R-IP3 16S rRNA (Marconi \& Garon, 1992a, b); Hpal sites, from Southern blotting data (this study) and the 16S rRNA sequences; Eagl, Bss HII and Smal sites, from data in this study, assuming identity with the B. burgdorferi 235 rRNA gene when assigning precise locations. Sites marked $(\mathrm{Bg})$ or $(\mathrm{Ba})$ were only found in $B$. garinii or $B$. afzelii, respectively. The Smal site marked (Bg*) was presented in B. garinii strains 20047, Ir210 and NBS16 but not strains NT29, PD89 and Sika1. CO1, CO2, etc. indicate the location of PCR amplimers listed in Table 3 . The 16 kbp mark on the scale corresponds to map locations $458 \mathrm{kbp}$ (B. burgdorferi), $469 \mathrm{kbp}$ (B. garinii) and $474 \mathrm{kbp}$ (B. afzelii). 
duplicated in these organisms. An $r r f$ probe hybridized with these PCR products, confirming that in each case $r r_{j}^{f}$ was located alongside the 3' end of $r r l$. A $3 \cdot 2 \mathrm{kbp}$ fragment: was seen in I-CeuI, $S m a \mathrm{I}, E a g \mathrm{I}$ and Bss HII digests of $B$. garinii and B. afzelii DNA (Table 2). The observation that these fragments hybridized with an $\mathrm{rr}$-specific probe was consistent with the presence of a $3 \cdot 2-\mathrm{kbp}$-long tandem duplication of $\mathrm{rrl}$ containing sites for each of these four enzymes (Fig. 2). PCR was carried out using CO8-CO6 as amplimers and a template of $B$. burgdorferi, B. garinii or $B$. afzelii DNA, then the reaction products were digested with SmaI, EagI or BssHII and the sizes of the digestion products were determined. For each enzyme the fragment sizes from the different templates were indistinguishable, indicating that the SmaI, EagI and Bss HII sites in the B. garinii and $B$. afzelii $r r l$ genes were in similar, if not identical, positions to those in the B. burgdorferi $\mathrm{rrl}$ genes (Fig. 2). The number of copies of the rrl rrf tandem repeat was calculated by using previously reported values for the sizes of EcoRV fragments that hybridized with a total RNA probe (Baranton et al., 1992). Summation of these sizes indicated that the rRNA genes were contained within $10.1 \mathrm{kbp}$ for B. garinii and $11.5 \mathrm{kbp}$ for B. afzelii. Given the sizes of $r r l$, rrf, rrs and the intervening DNA, it is not possible to contain more than two copies of the $\mathrm{rrl}$ rrf tandem repeat within these limits.

Juxtaposition of rrs and rrl. Digestion of $B$. burgdorferi DNA with $M l u I$ plus $B s s H I I$ yielded a $6.2 \mathrm{kbp}$ product that hybridized with the rrs probe (CO4- $\mathrm{CO} 5)$ but not the $r r l$ probe (CO1-CO6). By contrast, the corresponding fragment in digests of $B$. garinii and $B$. afzelii DNA was found to be $8.4 \mathrm{kbp}$. This and similar results with other enzyme digestions indicated the presence of an additional $2 \cdot 2 \mathrm{kbp}$ of DNA between $r r s$ and $r r l$ in $B$. garinii and $B$. afzelii compared with B. burgdorferi (Fig. 2b). This additional DNA contained an extra SmaI site (Fig. 2b) in B. garinii 20047 , yielding a $1.8 \mathrm{kbp} S \mathrm{maI}$ fragment (SmG) that hybridized to the $r r l$ probe CO8-CO9. The $S m a$ I site was not invariant in all B. garinii strains, being present in strains Ir210 and NBS16 but not NT29, PD89 and Sika1. It was absent from all the B. afzelii strains examined: VS461, BO23, ECM1 and IPer3.

\section{DISCUSSION}

Three species of spirochaete, B. burgdorferi, B. garinii and $B$. afzelii, have been implicated as aetiologic agents of Lyme borreliosis (Burgdorfer et al., 1982; Baranton et al., 1992; Canica et al., 1993). Of the three, B. burgdorferi has been studied most closely at the genomic level and was the first bacterium found to possess a linear chromosome (Baril et al., 1989; Ferdows \& Barbour, 1989; Davidson et al., 1992). Since that discovery, linear chromosomes have been found in other bacteria, e.g. Streptomyces lividans (Lin et al., 1993; Hinnebusch \& Tilly, 1993). The physical mapping studies presented in this publication confirm that the chromosomes of B. garinii and B. afzelii share this unusual property of linearity. Another unusual feature of the $B$. burgdorferi genome is its complement and organization of rRNA genes. Most bacteria contain equivalent numbers of each of the three rRNA genes grouped in rRNA operons (Krawiec \& Riley, 1990). Every operon contains a single copy of each gene, and commonly the operons are present in the chromosome in multiple copies. B. burgdorferi differs from this pattern because it has only one copy of $\mathrm{rrs}$ and two copies of $\mathrm{rrl}$ and $r r f$ (Fig. 2a) (Davidson et al., 1992; Schwartz et al., 1992; Fukunaga \& Sohnaka, 1992). Furthermore, the presence of $2.7 \mathrm{kbp}$ of DNA containing another gene in the opposite orientation between $\operatorname{rrs}$ and $\operatorname{rr} / A$ (ile $T$ ) suggests that $r r s$ is transcribed independently of the other rRNA genes (Gazumyan et al., 1994). Our PCR and hybridization analyses indicate that this unusual complement and organization of rRNA genes is also present in B. garinii and B. afzelii. This conclusion is in agreement with that reached by Schwartz et al. (1992) from an analysis of restriction fragment length polymorphisms in the B. burgdorferi sensu lato strains 20047 and IP3. Their strain 20047 has been reclassified as the B. garinii type strain and is the same as the strain used in this study, while their IP3, a Russian isolate also known as R-IP3 and IPer3, has been classified as B. afzelii (Canica et al., 1993; Marconi \& Garon, 1992b).

It had previously been observed that there is a high degree of conservation of cleavage site location in the chromosomes of two different isolates of the species $B$. burgdorferi (strains 212 and Sh-82-2) (Casjens \& Huang, 1993). The present work indicates that this conservation does not extend to an interspecies comparison, since the chromosomes of B. burgdorferi, B. garinii and B. afzelii were found to have few conserved endonuclease sites. The conserved sites occur mostly in a cluster in the rRNA genes $r r l$ and $r r s$, loci that are known to exhibit a high degree of sequence conservation (Marconi \& Garon, 1992b). This level of dissimilarity in the maps is not unexpected since the three bacterial genospecies exhibit less than $70 \%$ DNA cross-hybridization (Baranton $e t$ al., 1992; Canica et al., 1993) and the endonucleases used for the mapping had recognition sequences of 6 or more bp.

In contrast to the physical maps, the genetic maps of the three different species are extremely closely related. No differences between the gene order of the three chromosomes were observed, although the existence of small differences cannot be unequivocally ruled out because the genetic mapping could only be carried out at low resolution. Nevertheless, it is clear that there has been no large inversion or translocation involving a significant proportion of either of the three chromosomes. Because the sizes of the three chromosomes do not differ significantly, the occurrence of large-scale deletions or insertions can also be ruled out, except for the unlikely situation of compensating insertions and deletions. We conclude from this analysis that the chromosomes of the Lyme disease spirochaetes have not undergone major genetic rearrangements during the divergent evolution of the three species from their common ancestor, and that differences between the physical maps most likely result from base substitutions. This genetic stability may be 
related to the clonal properties of Borrelia (Dykhuizen $e t$ al., 1993).

Detailed analyses of the region of the chromosome that contains the rRNA genes revealed the presence of a DNA length polymorphism in the Lyme disease spirochaetes. Both B. garinii and B. afzelii contain an additional $2.2 \mathrm{kbp}$ of DNA between $r r s$ and $r r l A$. The function of this DNA and its coding properties, if any, are not known. Interestingly, the existence of this polymorphism is partly responsible for the restriction fragment length polymorphism which facilitated the discovery that $B$. burgdorferi sensu lato consists of three different genospecies (Baranton et al., 1992; Canica et al., 1993; Fukunaga et al., 1993). We have no data that shed light on the molecular nature of the genetic event responsible for the DNA length polymorphism. Its occurrence in the vicinity of rRNA genes may be significant, since the repeated sequences that result from the presence of multiple copies of these genes have been associated with the chromosomal rearrangement that characterizes the Escherichia coli $\mathrm{K} 12$ strain W3110 (Hill \& Harnish, 1981). The presence of enzymes that mediate genetic recombination in the Lyme disease Borrelia can be inferred from the observation of recombination between two related $B$. burgdorferi genes, osp. $A$ and $\operatorname{csp} B$ (Rosa et al., 1992). Determination of the nucleotide sequence between $r r s$ and $r r l A$ in $B$. garinii and $B$. afzelii and comparison of it with the known $B$. burgdorferi sequence (Gazumyan et al., 1994) should provide insights into the mechanism by which the polymorphism arose.

The genetic stability seen in the chromosomes of these three borrelial species is in contrast to the situation in another spirochaete, Leptospira interrogans, where the chromosomes of two serovars exhibited large rearrangements (Zuerner $e$ t al., 1993). Comparative genetic maps of four Bacillus cereus strains also indicate a significant degree of genomic plasticity in that organism (Carlson et al., 1992). On the other hand, marked genetic stability has been found in the chromosomes of ten Clostridium perfringens strains (Canard et al., 1992) and five Mycoplasma bominis strains (Ladefoged \& Christiansen, 1992), while different strains of Mycoplasma mycoides subsp. mycoides have few differences in their chromosomal gene order (Pyle et al., 1990). The well-characterized congruence between the genetic maps of E. coli and Salmonella typhimurium and their similarities with the Shigella flexneri map is another example of long-term retention of gene order (Riley \& Krawiec, 1987; Okada et al., 1991). In the future it is likely that the availability of a more extensive database on genetic variation in different bacterial species and genera will enable a meaningful evaluation to be made of the relative genetic stability in any one genus. At present the data are too limited to allow us to conclude whether or not the Lyme disease Borrelia are exceptional in terms of the stability of their chromosome.

\section{ACKNOWLEDGEMENTS}

W'e are most grateful to Elisabeth Bellenger and Danielle
Margarita for invaluable and skilful assistance with the experimental work, to Daniele Postic for samples of Borrelia DNA, to Guy Baranton for comments on the manuscript, and to Ira Schwartz for sending us his manuscript prior to publication. We are also grateful to Nyles Charon, Alan Barbour, Joe Hinnebusch, Kit Tilly, Bettina Wilske, Dieter Rößler and Peter Hindersson for giving us molecular clones for genetic mapping studies. This work was supported by grants from the G. Harold and Leila Y. Mathers Charitable Foundation to the Institut Pasteur and the Australian Research Council to BED.

\section{REFERENCES}

Assous, M. V., Postic, D., Paul, G., Névot, O. \& Baranton, G. (1993). Western blot analysis of sera from Lyme borreliosis patients according to the genomic species of the Borrelia strains used as antigens. Eur J Clin Microbiol \& Infect Dis 12, 261-268.

Baranton, G., Postic, D., Saint Girons, I., Boerlin, P., Piffaretti, J.C., Assous, M. \& Grimont, P. A. D. (1992). Delineation of Borrelia burgdorferi sensu stricto, Borrelia garinii sp. nov., and group VS461 associated with Lyme borreliosis. Int J Syst Bacteriol 42, 378-383.

Barbour, A. G. (1984). Isolation and cultivation of Lyme disease spirochetes. Yale J Biol Med 57, 521-525.

Baril, C., Richaud, C., Baranton, G. \& Saint Girons, I. (1989). Linear chromosome of Borrelia burgdorferi. Res Microbiol 140, 507-516.

Burgdorfer, W., Barbour, A. G., Hayes, S. F., Benach, J. L., Grunwaldt, E. \& Davis, J. P. (1982). Lyme disease - a tick-borne spirochetosis? Science 216, 1317-1319.

Canard, B., Saint-Joanis, B. \& Cole, S. T. (1992). Genomic diversity and organization of virulence genes in the pathogenic anaerobe Clostridium perfringens. Mol Microbiol 6, 1421-1429.

Canica, M. M., Nato, F., du Merle, L., Mazie, J. C., Baranton, G. \& Postic, D. (1993). Monoclonal antibodies for identification of Borrelia afzelii sp. nov. associated with late cutaneous manifestations of Lyme borreliosis. Scand J Infect Dis 25, 441-448.

Carlson, C. R., Grønstad, A. \& Kolstø, A.-B. (1992). Physical maps of the genomes of three Bacillus cereus strains. J Bacteriol 174, $3750-3756$.

Carniel, E., Mercereau-Puijalon, O. \& Bonnefoy, S. (1989). The gene coding for the 190,000-dalton iron-regulated protein of Yersinia species is present only in the highly pathogenic strains. Infect Immun 57, 1211-1217.

Casjens, S. \& Huang, W. M. (1993). Linear chromosomal physical and genetic map of Borrelia burgdorferi, the Lyme disease agent. Mol Microbiol 8, 967-980.

Davidson, B. E., MacDougall, J. \& Saint Girons, I. (1992). Physical map of the linear chromosome of the bacterium Borrelia burgdorferi 212, a causative agent of Lyme disease, and localization of rRNA genes. J Bacteriol 174, 3766-3774.

Dykhuizen, D. E., Polin, D. S., Dunn, J. J., Wilske, B., Preac-Mursic, V., Dattwyler, R. J. \& Luft, B. J. (1993). Borrelia burgdorferi is clonal: implications for taxonomy and vaccine development. Proc Natl Acad Sci USA 90, 10163-10167.

Feinberg, A. P. \& Vogelstein, B. (1984). A technique for radiolabeling DNA restriction endonuclease fragments to high specific activity. Anal Biochem 137, 266-267.

Ferdows, M. S. \& Barbour, A. G. (1989). Megabase-sized linear DNA in the bacterium Borrelia burgdorferi, the Lyme disease agent. Proc Natl Acad Sci US A 86, 5969-5973.

Fukunaga, M. \& Sohnaka, M. (1992). Tandem repeat of the $23 \mathrm{~S}$ and 
$5 S$ ribosomal RNA genes in Borrelia burgdorferi, the etiological agen: of Lyme disease. Biochem Biophys Res Commun 183, 952-957.

Fukunaga, M., Sohnaka, M. \& Yanagihara, Y. (1993). Analysis of Borrelia species associated with Lyme disease by rRNA gene restriction fragment length polymorphism. J Gen Microbiol 139, 1141-1146.

Gassmann, G. S., Jacobs, E., Deutzmann, R. \& Göbel, U. B. (1991). Analysis of the Borrelia burgdorferi GeHo $f a$ gene and antigenic characterization of its gene product. J Bacteriol 173, 1452-1459.

Gazumyan, A., Schwartz, J. J., Liveris, D. \& Schwartz, I. (1994). Sequence analysis of the ribosomal RNA operon of the Lyme disease spirochete Borrelia burgdorferi. Gene (in press).

Hansen, K., Bangsborg, J. M., Fjordvang, H., Pedersen, N. S. \& Hindersson, P. (1988). Immunochemical characterization of and isolation of the gene for a Borrelia burgdorferi immunodominant 60 kilodalton antigen common to a wide range of bacteria. Infect Immun 56, 2047-2053.

Hill, C. W. \& Harnish, B. W. (1981). Inversions between ribosomal RNA genes of Eschericbia coli. Proc Natl Acad Sci USA 78, 7069-7072.

Hinnebusch, J. \& Barbour, A. G. (1991). Linear plasmids of Borrelia burgdorferi have a telomeric structure and sequence similar to those of a eukaryotic virus. J Bacteriol 173, 7233-7239.

Hinnebusch, J. \& Tilly, K. (1993). Linear plasmids and chromosomes in bacteria. Mol Microbiol 10, 917-922.

Hinnebusch, J., Bergström, S. \& Barbour, A. G. (1990). Cloning and sequence analysis of linear plasmid telomeres of the bacterium Borrelia burgdorferi. Mol Microbiol 4, 811-820.

Howe, T. R., Mayer, L. W. \& Barbour, A. G. (1985). A single recombinant plasmid expressing two major outer surface proteins of the Lyme disease spirochete. Science 227, 645-646.

Jauris-Heipke, S., Fuchs, R., Hofmann, A., Lottspeich, F., PreacMursic, V., Soutschek, E., Will, G. \& Wilske, B. (1993). Molecular characterization of the $p 100$ gene of Borrelia burgdorferi strain PKo FEMS Microbiol Lett 114, 235-242.

Johnson, R. C., Schmid, G. P., Hyde, F. W., Steigerwalt, A. G. \& Brenner, D. J. (1984). Borrelia burgdorferi sp. nov. : etiologic agent of Lyme disease. Int J Syst Bacteriol 34, 496-497.

Krawiec, S. \& Riley, M. (1990). Organization of the bacterial chromosome. Microbiol Rev 54, 502-539.

Ladefoged, S. A. \& Christiansen, G. (1992). Physical and genetic mapping of the genomes of five Mycoplasma bominis strains by pulsed-field gel electrophoresis. J Bacteriol 174, 2199-2207.

Lin, Y.-S., Kieser, H. M., Hopwood, D. A. \& Chen, C. W. (1993). The chromosomal DNA of Streptomyces lividans 66 is linear. Mol Microbiol 10, 923-933.

Marconi, R. T. \& Garon, C. F. (1992a). Phylogenetic analysis of the genus Borrelia: a comparison of North American and European isolates of Borrelia burgdorferi. J Bacteriol 174, 241-244.

Marconi, R. T. \& Garon, C. F. (1992b). Identification of a third genomic group of Borrelia burgdorferi through signature nucleotide analysis and 16S rRNA sequence determination. J Gen Microbiol 138, 533-536.

Okada, N., Sasakawa, C., Tobe, T., Talukder, K. A., Komatsu, K. \& Yoshikawa, M. (1991). Construction of a physical map of the chromosome of Shigella flexneri $2 \mathrm{a}$ and the direct assignment of nine virulence-associated loci identified by $\operatorname{Tn} 5$ insertions. Mol Microbiol 5, 2171-2180.

Old, I. G., MacDougall, J., Saint Girons, I. \& Davidson, B. E. (1992a). Mapping of genes on the linear chromosome of the bacterium Borrelia burgdorferi: possible locations for its origin of replication. FEMS Microbiol Lett 99, 245-250.

Old, I. G., Margarita, D. \& Saint Girons, I. (1992b). Nucleotide sequence of the Borrelia burgdorferi $r p m H$ gene encoding ribosomal protein L34. Nucleic Acids Res 20, 6097.

Old, I. G., Margarita, D. \& Saint Girons, I. (1993a). Unique genetic arrangement in the dna $A$ region of the Borrelia burgdorferi linear chromosome: nucleotide sequence of the dnaA gene. FEMS Microbiol Lett 111, 109-114.

Old, I. G., Margarita, D. \& Saint Girons, I. (1993b). Nucleotide sequence of the Borrelia burgdorferi dna $N$ gene encoding the $\beta$ subunit of DNA polymerase III. Nucleic Acids Res 21, 3323.

Pyle, L. E., Taylor, T. \& Finch, L. R. (1990). Genomic maps of some strains within the Mycoplasma mycoides cluster. J Bacteriol 172, 7265-7268.

Reed, K. C. \& Mann, D. A. (1985). Rapid transfer of DNA from agarose gels to nylon membranes. Nucleic Acids Res 13, 7207-7221.

Riley, M. \& Krawiec, S. (1987). Genome organization. In Escherichia coli and Salmonella typhimurium: Cellular and Molecular Biology, pp. 967-981. Edited by F. C. Neidhardt, J. L. Ingraham, K. B. Low, B. Magasanik, M. Schaechter \& H. E. Umbarger. Washington, DC: American Society for Microbiology.

Rosa, P. A., Hogan, D. \& Schwan, T. G. (1991). Polymerase chain reaction analyses identify two distinct classes of Borrelia burgdorferi. J Clin Microbiol 29, 524-532.

Rosa, P. A., Schwan, T. \& Hogan, D. (1992). Recombination between genes encoding major outer surface proteins $A$ and $B$ of Borrelia burgdorferi. Mol Microbiol 6, 3031-3040.

Saint Girons, I., Old, I. G. \& Davidson, B. E. (1994). Molecular biology of the Borrelia, bacteria with linear replicons. Microbiology 140, 1803-1816.

Schwartz, J. J., Gazumyan, A. \& Schwartz, I. (1992). rRNA gene organization in the Lyme disease spirochaete, Borrelia burgdorferi.J Bacteriol 174, 3757-3765.

Tilly, K. \& Campbell, J. (1993). A Borrelia burgdorferi homolog of the Escherichia coli rho gene. Nucleic Acids Res 21, 1040.

Tilly, K., Hauser, R., Campbell, J. \& Ostheimer, G. J. (1993). Isolation of dnaJ, dnaK and grpE homologues from Borrelia burgdorferi and complementation of Escherichia coli mutants. Mol Microbiol 7, 359-369.

Tulloch, D. L., Finch, L. R., Hillier, A. J. \& Davidson, B. E. (1991). Physical map of the chromosome of Lactococcus lactis subsp. lactis DL11 and localization of six putative rRNA operons. $J$ Bacteriol 173, 2768-2775.

Zuerner, R. L., Herrmann, J. L. \& Saint Girons, I. (1993). Comparison of genetic maps for two Leptospira interrogans serovars provides evidence for two chromosomes and intraspecies heterogeneity. J Bacteriol 175, 5445-5451.

Received 6 May 1994; revised 12 July 1994; accepted 19 July 1994. 